\title{
Physical Activity Measurement
}

National Cancer Institute

\section{Source}

National Cancer Institute. Physical Activity Measurement. NCI Thesaurus. Code C120914.

A measurement of a subject's physical activity or movement. 